\title{
Review
}

\section{Emanuel Levinas and the politics of non-violence}

\author{
Victoria Tahmasebi-Birgani \\ University of Toronto Press, Toronto, 2014, 224pp., ISBN: 978-1442642843 \\ Contemporary Political Theory (2015) 14, e19-e21. doi:10.1057/cpt.2014.39; \\ published online 9 December 2014
}

This is a challenging and radical book that offers a bold and insightful analysis of Levinas's ethics and affirms his relevance to political thinking, with particular focus on its potential for the ideology and praxis of political liberation. This is an aspect of his work that has been rather neglected in more recent critiques, as most academics have felt that reconciling Levinas's thinking to politics is rather akin to putting a square peg into a round hole. Yet this will clearly not do for the author, who is on a mission to rescue Levinasian ethics from amounting to little more than a 'pious discourse'. It is certainly an enterprise that will be attractive to many Levinasian scholars for its forceful presentation of the argument that the implications of Levinas's philosophy of alterity have resonance in the political domain - although the author employs a certain elasticity in her interpretation of his thinking and takes it possibly further than Levinas himself would have intended.

For Tahmasebi-Birgani, Levinas is much more than a thinker of an attractive, albeit esoteric, code of ethical behaviour that (in the eyes of many of his critics of a liberal orientation) is dirempted from ontological considerations. Instead she situates the face-to-face ethical encounter between the subject and the other squarely within politics, which she explores in the first chapter. She argues that his thinking is directed towards the political because the ethical encounter, and the dilemma of accommodating the other's absolute alterity, lies at its very core. This is because the subject's own self-directed concerns are displaced as the origin of politics and are instead derived from the subject's irreducible responsibility for the other, which is the genesis of freedom.

How does one advance the cause of the suffering other? Almost invariably, the author notes, revolutions are reactions to, and antitheses of liberal capitalism, and become 'prisoners to that which they aimed to negate' (p. 24). An opportunity has been missed; that is, they failed to incorporate the one-for-the-other as the cornerstone of their revolutionary creed, and so could not find the 'me' or seek the other, and were thus no more than totalising political projects. Tahmasebi-Birgani addresses a problem that other Levinasian scholars have found insurmountable,

(C) 2015 Macmillan Publishers Ltd. 1470-8914 Contemporary Political Theory Vol. 14, 3, e19-e21 
because Levinas's ethics are based on a dyadic encounter between the subject and the other, which is compromised the moment that the third arrives on the scene. Her solution to this is elegant in its simplicity: every human performs the role of subject, other and the third, and therefore the third is present in the encounter as the other. It follows that the ethical is already in the socio-political, and - although this reviewer has certain issues with her reading of Levinas on this critical point - she accepts that it is one that will have a broad appeal, particularly to those who would otherwise feel that such a model of ethics is disengaged from politics.

This account of Levinasian ethics, therefore, is more grounded than those that have commonly been provided. It will be attractive to many readers of Levinas because it offers the possibility of a philosophical move from his thinking on ethics to his political thinking by showing how they are already linked. TahmasebiBirgani thereby counters the claim that his ethics fail to survive first contact with ontological reality. If every human is the other, then the 'me' bears responsibility for all others, so the introduction of justice is not needed to subdue (an)archic responsibility but rather is a consequence of it, so that the face of the other becomes the very site of the social demand for justice as a passionate concern for her well-being.

The potential contained within Levinas's theory of substitution, to serve as a model of political non-violence, is another key theme that is explored by the author. The exposure of 'me' emerges as a modality of radical passivity, thereby becoming 'the concretion of the subject's non-indifference to the other's suffering' (p. 82) and to the plea contained in her face. This is an affirmative instant that offers to the subject the possibility of action in substituting for the suffering of the other a praxis that is 'to rebel against injustice while respecting the face of the persecutor' (p. 113). Resistance to oppression is an imperative that eschews the path of violence.

For Levinasian thinking as 'liberatory praxis' the author looks to Gandhi - the political activist and intellectual who led and inspired the struggle against British colonialism - and reminds us that he inspired Nelson Mandela and Martin Luther King, Jr. This is an inspired choice, because, as she demonstrates, there are clear similarities in the thinking of Levinas and Gandhi as 'both present a radical critique of the autonomous, rational subject of modernity and deeply problematised the idea of human reason and progress as the sole means and end of human life' (p. 116). The author explores the similarities, including Gandhian selfless service and Levinasian irreplaceable responsibility, and the respective positions of the two on non-violent struggle. The author compares Gandhi's philosophy of Satyagraha as political and non-violent resistance to injustice coupled with the responsibility 'to see the enemy as a human being and to refuse to obliterate her face' (p. 129). Through Gandhi's inspirational leadership passive resistance equipped his movement with a moral force, which the British proved powerless to resist and demonstrated that it is possible for right to make might. 
However, despite some startling similarities in the thinking of the two men, it is hard not to feel that Tahmasebi-Birgani is not stretching her case perhaps a little more than the evidence suggests. She suggests that in the span of almost 50 years of writing Levinas only occasionally lent support to the liberal state - a proposition that is certainly contentious. She also suggests that his acknowledgement that 'the liberal state has always admitted, alongside the liberal law, human rights as a parallel institution' is unambiguous. This reflects his view, consistently, that it 'is more moral than the fascist state and closer to the morally ideal state' (Wright et al, 1988). The word 'parallel' here is significant, because Levinas is not seeking to supplant Western notions of justice. He insists that 'everything I say about justice comes from Greek thought' (ibid, p. 174). His ethics stalks modern philosophical thought, calling it to conscience.

It is a shame that the opportunity was not taken to address in much more detail Levinas's position on Israel's dealings with the Palestinians that earned him a great deal of censure and opprobrium. Given that it is the most cited example of his failure to apply his ethics concretely, the discussion should have merited more attention than a couple of cursory references and a single paragraph. A more extended discussion of this highly problematic issue would have been welcome as it is often cited in support of the claim that, when put on the spot, Levinas abandons his own philosophy in favour of solidarity with 'his people', thus turning his back on the Palestinians - a serious charge that in the context of the book's subject deserves a fuller response.

My final point is that the selection of Gandhi itself, while apposite and rewarding, serves to underline the limitations of Levinasian thinking as liberatory praxis. What becomes of a liberation that does not consume its violence? In the case of India post1948 the answer is that it falls back into the clutches of a state that is modelled, however unconvincingly, on democratic lines, suggesting that revolutionary struggles appear to share a common fate because their ideals prove impossible to sustain. However, despite certain reservations, such as those discussed above, TahmasebiBirgani pursues the topic with confidence and panache. The result is a work that is a challenging and stimulating addition to the study of Levinasian ethics, which will appeal to those academics searching to find a way to make it relevant to, and engaged with, the political domain.

\section{Reference}

Wright, T., Hughes, P. and Ainley, A. (1988) The paradox of morality: An interview with Emmanuel Levinas. In: R. Bernasconi and D. Wood (eds.) The Provocation of Levinas. London: Routledge, p. 188.

Amanda Loumansky Middlesex University, London NW4 4BT, UK 